\title{
Migration patterns of four Asian Houbara Chlamydotis macqueenii wintering in the Cholistan Desert, Punjab, Pakistan
}

\author{
CHRISTOPHE TOURENQ, OLIVIER COMBREAU, \\ MARK LAWRENCE and FREDERIC LAUNAY
}

\begin{abstract}
Summary
Migration patterns of four Asian Houbara Chlamydotis macqueenii wintering in the Cholistan Desert, Pakistan in 1998 were monitored using satellite transmitters. Their homeward migration began between 15 and 31 March, and they arrived on breeding grounds in China, Mongolia and Uzbekistan between 16 and 27 May. The houbara stayed on their breeding areas for $c .135$ days (range $=124-140$ ). They arrived on the wintering grounds in the Cholistan Desert between 20 October and 15 December. During their migration, they avoided the mountain massifs of Hindu Kush, Pamir, Tien Shan and Himalaya. They could fly up to $220 \mathrm{~km} \mathrm{day}^{-1}$ and covered a total distance of up to $4,400 \mathrm{~km}$ between their departure and destination points. Long stopovers were made mainly in the Registan Desert (Afghanistan), the Kyzylkum Desert (Uzbekistan/ Kazakhstan), the Muyunkum and Taukum Deserts (Kazakhstan) and to a lesser extent the Zhob Valley (Pakistan). Conservation issues of a long-distance migrant species like Asian Houbara should be addressed at a broader scale through an international collaboration between Central Asian countries, from the breeding grounds of China to the wintering grounds of the Indian subcontinent.
\end{abstract}

\section{Introduction}

Asian Houbara (recently reclassified as a full species, Chlamydotis macqueenii, previously subspecies Chlamydotis undulata macqueenii; Knox et al. 2002) is a desert and steppe dwelling bustard distributed from Mongolia to the Arabian Peninsula, through Central Asia (del Hoyo et al. 1996). It is classified as "lower risk/near threatened", i.e. "facing a high risk of extinction in the wild in the medium-term future" (Hilton-Taylor 2000, see http://www.redlist.org). Asian Houbara (hereafter "houbara") populations are apparently declining dangerously throughout their distribution due to poaching, excessive hunting by falconers, and a general impoverishment and fragmentation of their habitat (Collar 1979, Goriup 1997, Rahmani and Soni 1997, Combreau et al. 2001).

Pakistan is one of the main wintering areas for houbara (Goriup 1997, Combreau et al. 2001). It is also one of the countries where they are at greatest risk from hunting and poaching (Combreau et al. 2001). Until the mid 1980s, the number of houbara killed during falconry hunting parties in Pakistan reached between 3,000 and 7,000 birds each year, but this number has since been reduced to a few hundred birds (Pakistan National Report to CMS in Goriup 1997). 
Despite this decrease however, houbara are still heavily poached in Pakistan and sent live to the Arabian Peninsula for falcon training purposes (Bailey et al. 1999). The number of houbara taken by poachers has been estimated to range between 4,000 and 7,000 individuals per annum solely for Pakistan (Goriup 1997). In this context, a collaboration was initiated between the National Avian Research Center of the Environmental Research and Wildlife Development Agency of Abu Dhabi, UAE, and the Houbara Foundation International, based in Lahore, Pakistan, to promote the conservation of houbara in Pakistan.

For migratory birds like houbara, the identification of migratory routes and stopover areas is crucial to any effective conservation effort (Berthold 1993, Webster et al. 2002). Due to their cryptic behaviour and low densities on their wintering grounds, monitoring of houbara movements using traditional tagging methods is difficult and satellite tracking has been shown to be an efficient tool for this purpose (Osborne et al. 1997, Combreau et al. 1999). We present in this paper the monitoring of movement patterns of four birds captured and equipped with satellite transmitters in 1998 whist wintering in the Cholistan Desert, Province of Punjab, Pakistan.

\section{Methods}

Covering c. $26,000 \mathrm{~km}^{2}$ on the eastern bank of the Indus River, the Cholistan Desert $\left(28^{\circ}-30^{\circ} \mathrm{N}, 71^{\circ}-73^{\circ} \mathrm{E}\right)$ is a part of the huge Tahr Desert $\left(\right.$ c. $\left.238,700 \mathrm{~km}^{2}\right)$ that extends from Pakistan to western Rajasthan in India. Its climate is extreme: annual temperatures can range from near-freezing in the winter (OctoberFebruary) to more than $50{ }^{\circ} \mathrm{C}$ during the summer (March-June). Most (85\%) rainfall is received through the short July-September southwest monsoon that brings a mere $100-400 \mathrm{~mm}$ of precipitation. About $10 \%$ of the ecoregion is composed of sand dunes, the rest being craggy rock forms, compacted salt-lake bottoms, and interdunal and fixed dune areas (Rahmani and Soni 1997, Rawat and Wikramanayake 2001).

At the beginning of March 1998, four houbara were captured using a disarmed falcon with plastic beads glued to the point of each claw and an adapted hood that allowed the bird to see but prevented the use of its beak with a beak guard. This has been assessed previously as a method to capture houbara with a minimised risk of injury to the houbara during capture (Seddon et al. 1999). The houbara were equipped with a PTT (platform transmitter terminal) and released within one hour of capture. Birds were monitored over the following days using a Gonio receiver (IESM Gonio 40oP) to check any post-release problems. The battery powered Microwave nano PTT (Microwave Telemetry Inc. Columbia, Maryland) used in this study weighed c. $34 \mathrm{~g}$ including the harness, and constituted less than $3 \%$ of the houbara body mass.

Bird location data were collected through the ARGOS system that classifies locations according to seven accuracy classes from best to worst. In this paper, we used only ARGOS classes 1, 2, and 3 as well as the ARGOS class o that passed a repetitiveness test based on proximity of successive location estimates. Location data were entered into databases and plotted using ArcGIS (ESRI Inc., Redlands, California). Distances were calculated between stopovers over the entire migration route. The total migration distance was the sum of these 
segments. We classified stopovers as "short" ( $1-7$ days) and "long" ( $\geq 7$ days) according to Combreau et al. (1999).

\section{Results}

Three females (A,B,C) and one male (D) were captured and tagged with PTTs in the Cholistan Desert on the 9 and 10 March 1998 (Table 1). Post-capture monitoring revealed that none of the birds released were injured during the capture. The PTTs transmitted between 283 and 363 days and we gathered between 415 and 666 good locations without interruption (Table 1). The four houbara were monitored during their whole homeward and outward migration (='out-and-return migration', sensu Berthold 1996).

\section{Migration pathways}

All the houbara tagged in the Cholistan Desert moved northwestwards then northeastwards avoiding the Hindu Kush, Pamir, Tien Shan and Himalayan massifs (Figures 1 and 2). After crossing the Indus Valley in Pakistan, two females $(B, C)$ moved to the Zhob Valley before entering Afghanistan; the male (D) and a female (A) moved southwards through the Bolan Pass. Apart from one female $(C)$ that flew more to the north, all the birds crossed Afghanistan through the Registan Desert, east from Kandahar, and all then moved north towards east Turkmenistan and southeast Uzbekistan. One female (B) made an incursion into the Mashhad area, northeastern Iran, before flying to Turkmenistan. The houbara breeding in Mongolia (A,D) and China (C) continued towards Kazakhstan, crossing the desert plains of Muyunkum. The male (D) flew north of Lake Balkash, passed the Irtysh Valley and over the Altai Mountains before reaching his breeding site west of Uus Nuur Lake, northwestern Mongolia. Two females $(\mathrm{A}, \mathrm{C})$ flew south of Lake Balkash, and the other female (A) passed the Emel Valley, crossed the northern Jungar Desert and the Altai Mountains to reach her breeding site southeast of the Great Lakes Valley, western Mongolia. One female (B) flew further to the south and reached her breeding site of the Jungar Basin through the Alatau Shankou Pass.

After the breeding season, all the birds followed roughly the same migration pathways as during their homeward migration. However, the male (D) passed south of Lake Balkash and crossed Afghanistan straight from Turkmenistan to the Zhob Valley in Pakistan, north of his previous homeward route. One female

Table 1. Characteristics of houbara captured in the Cholistan Desert, Pakistan, 1998.

\begin{tabular}{|c|c|c|c|c|c|c|c|c|}
\hline Individual & PTT & $\begin{array}{l}\text { Ring } \\
\text { no. }\end{array}$ & $\begin{array}{l}\text { Weight } \\
(\mathrm{g})\end{array}$ & Sex & $\begin{array}{l}\text { Catch date } \\
(\mathrm{dd} / \mathrm{mm} / \mathrm{yy})\end{array}$ & $\begin{array}{l}\text { End } \\
\text { transmission } \\
(\mathrm{dd} / \mathrm{mm} / \mathrm{yy})\end{array}$ & $\begin{array}{l}\text { Transmission } \\
\text { period(days) }\end{array}$ & $\begin{array}{l}\text { Number of } \\
\text { class o and } \\
\text { above }\end{array}$ \\
\hline A & 28122 & No394 & 1,200 & Female & 09/03/98 & $07 / 03 / 99$ & 363 & 666 \\
\hline B & 28136 & $\mathrm{No}_{3} 85$ & 1,250 & Female & $10 / 03 / 98$ & $18 / 12 / 98$ & 283 & 415 \\
\hline $\mathrm{C}$ & 28137 & No168 & 1,250 & Female & $10 / 03 / 98$ & $24 / 03 / 99$ & 379 & 904 \\
\hline $\mathrm{D}$ & 28139 & No389 & 1,100 & Male & $09 / 03 / 98$ & $09 / 02 / 99$ & 337 & 498 \\
\hline
\end{tabular}

PTT, platform transmitter terminal. 


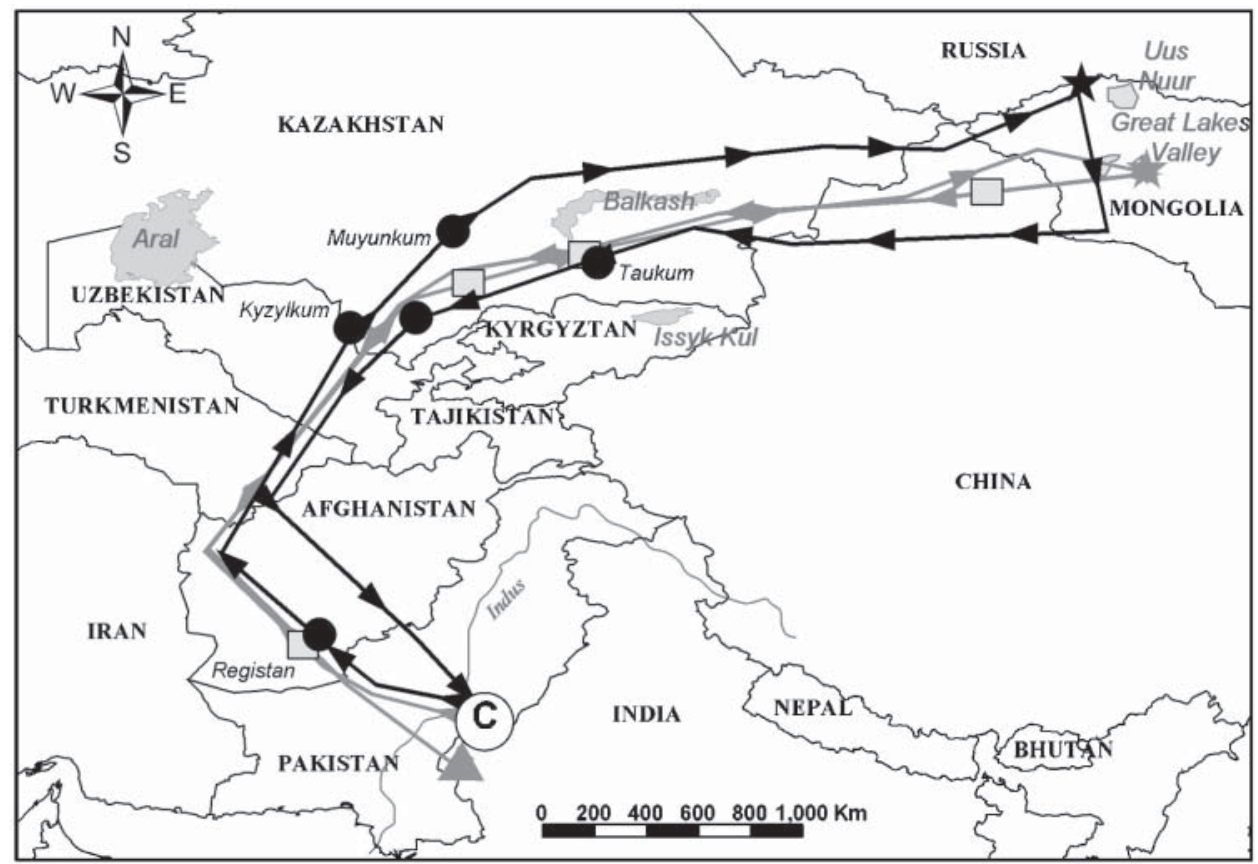

Figure 1. Migration routes and stopovers of two Asian Houbara: A (in grey) and D (in black) captured in the Cholistan Desert, Pakistan. C, capture site; stars, breeding sites; plain circles and squares, long stopovers ( $\geq 7$ days).

(C) crossed Afghanistan south of her previous homeward route to cross into Pakistan through the Bolan Pass. One female (B) did not stop in Iran and flew $c$. $360 \mathrm{~km}$ less than during her homeward migration. One female $(\mathrm{A})$ wintered in Indian Rajasthan, south of her previous Cholistan wintering site. Despite these differences, the distances covered by houbara during their outward migration were similar to those covered during their homeward migration.

\section{Migration timing}

Homeward migration starting dates ranged from 15 March to 31 March (Table 2). Arrival on the breeding grounds ranged from 15 to 27 May. The male (D) and one female (A) moved northeastwards to Mongolia (Figure 1), both flying c. $4,400 \mathrm{~km}(4,350 \mathrm{~km}$ for D and $4,400 \mathrm{~km}$ for A) from the Cholistan Desert in 61 and 53 days respectively (Table 2). One female (B) flew 2,100 km northwestwards to Uzbekistan in 48 days and another (C) flew $3,500 \mathrm{~km}$ northeastwards to China in 57 days (Figure 2).

The houbara stayed a mean of 135 days (range $=124-140$ ) on their breeding areas before starting their outward migration (Table 2). Departure for outward migration ranged from 13 September to 14 October, the Uzbek and the Chinese houbara being the first and the last to leave respectively. Arrival on the wintering grounds ranged from 20 October to 15 December. Two females $(B, C)$ and the male (D) reached their wintering grounds in the Cholistan Desert after 


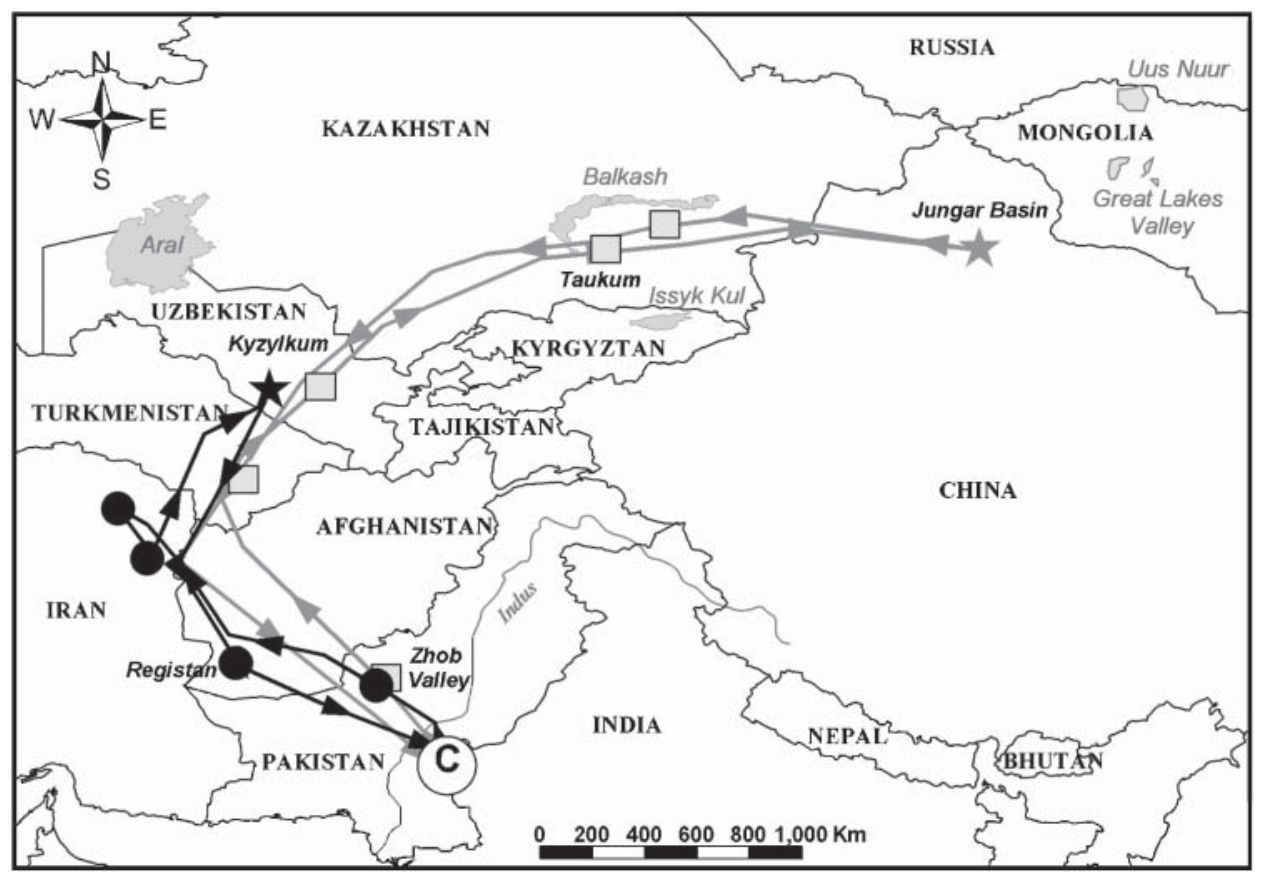

Figure 2. Map of migration routes and stopovers of two Asian Houbara: B (in black) and C (in grey) captured in the Cholistan Desert, Pakistan. C, capture site; stars, breeding sites; plain circles and squares, long stopovers ( $\geq 7$ days).

29-93 days, whilst the other female (A) reached the western bank of the Indus River after 20 days (Table 2). Overall daily travel distances during homeward migration (mean $=64.5 \mathrm{~km} \mathrm{day}^{-1}$, range $=43-82$ ) were half that during outward migration $\left(\right.$ mean $=123 \mathrm{~km} \mathrm{day}^{-1}$, range $\left.=19-220\right)$.

\section{Stopovers}

Houbara made about twice as many long ( $\geq 7$ days) and short $(<7$ days) stopovers during the homeward than the outward migration (Table 2). The mean distance between two successive stopovers was shorter during the homeward migration (300 $\mathrm{km}$, range $=74-1,770)$ than during the outward migration $(530 \mathrm{~km}$, range $=95-1,337)$. This difference is particularly reflected in the shorter distance between two successive short stopovers during homeward migration $($ mean $=307 \mathrm{~km}$, range $=74-949)$ compared to outward migration $($ mean $=574 \mathrm{~km}$, range $=95-1,337)$. The mean distance between long stopovers during the homeward migration was $857 \mathrm{~km}$ (range $=200-1,770$ ). Long stopovers were mainly distributed in the Registan Desert (Afghanistan), the Kyzylkum Desert (Uzbekistan/Kazakhstan), the Muyunkum and the Taukum (south of Lake Balkash) deserts (Kazakhstan) and to a less extend the Zhob Valley in Pakistan (Table 3). During the homeward migration, the first long stopovers were generally located closer $($ mean $=505 \mathrm{~km}$, range $360-650)$ to the departure point than during the outward migration ( mean $=996 \mathrm{~km}$, range $=430-1,980$; Table 3 ). Excluding 


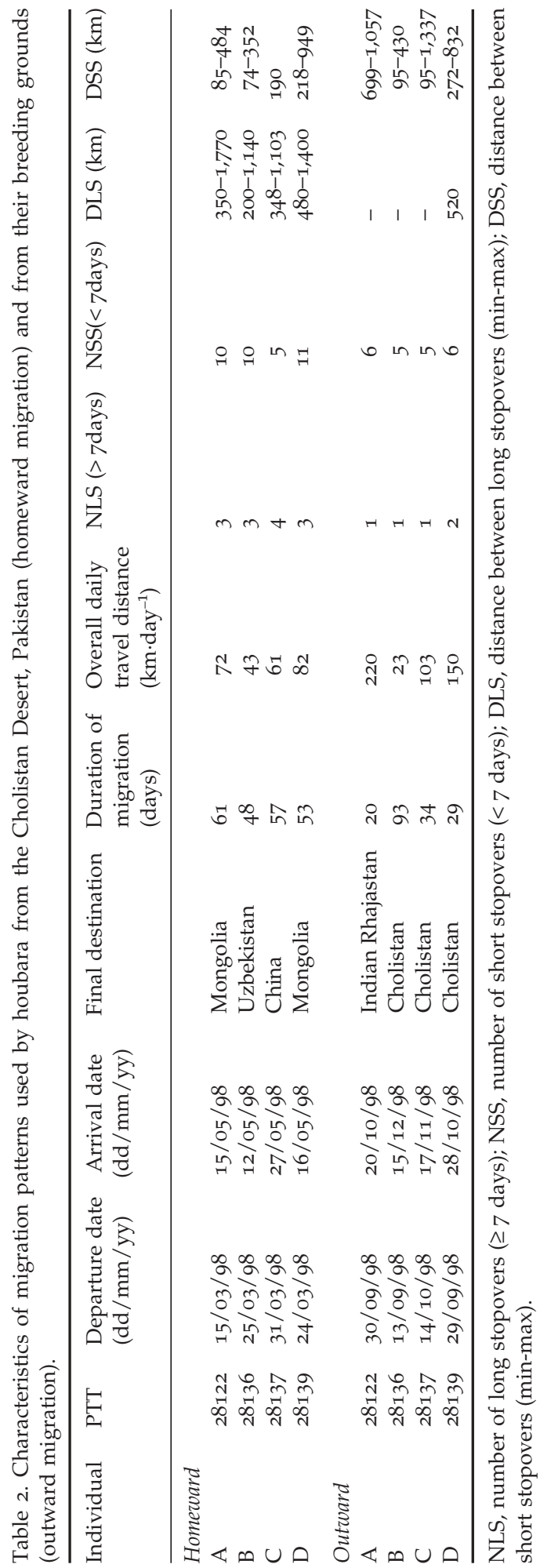




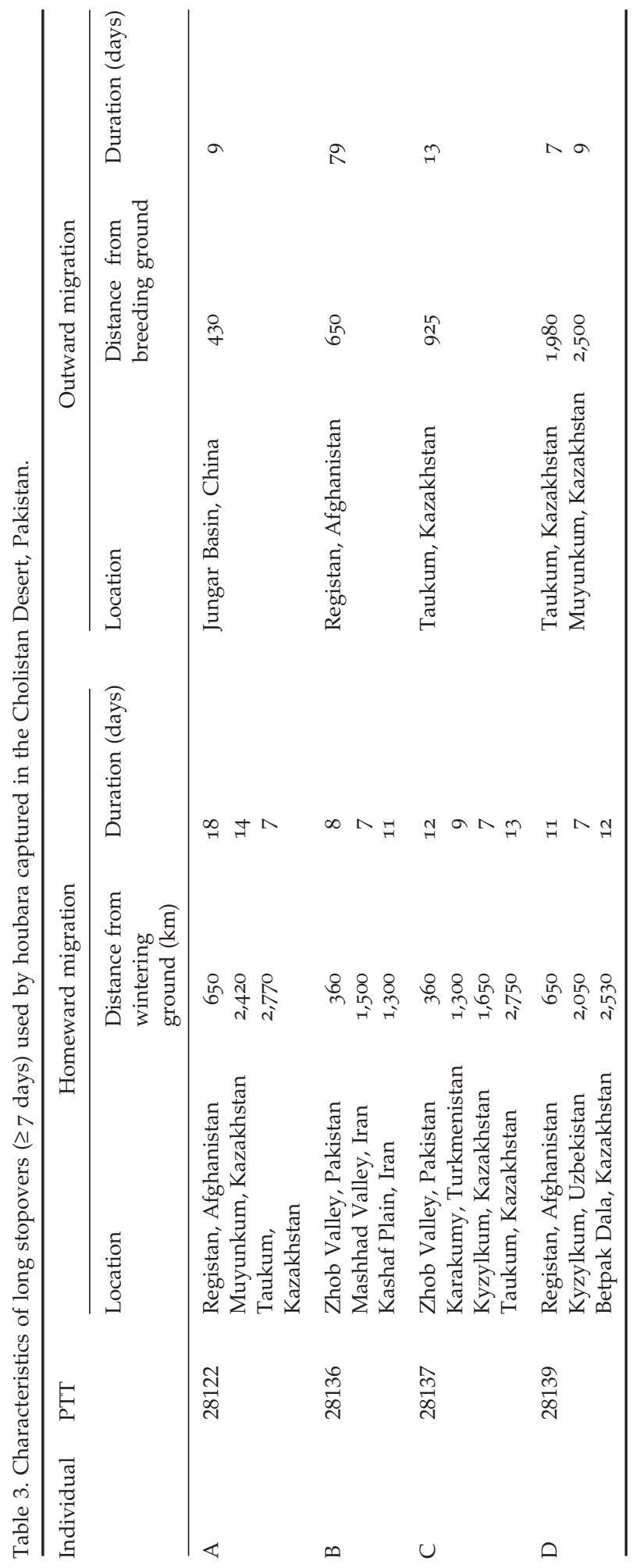


the stopover of 79 days in the Registan Desert by female B, mean duration of long stopovers during the homeward and the outward migration were similar (10.5 and 9.5 days, respectively; Table 3).

\section{Discussion}

In a similar study, Combreau et al. (1999) showed that eastern Kazakh houbara populations from the Taukum Desert (South Balkash region) wintered in Afghanistan and Iran. According to our data, houbara wintering in Pakistan and northwest India originate from the northeastern population widespread between Uzbekistan and Mongolia. The houbara tagged in the Cholistan Desert started their migration to breeding grounds between 15 and 31 March, reaching their breeding grounds in Uzbekistan, China and Mongolia 48, 57, and 53-61 days later, respectively. Female $\mathrm{C}$ arrived on her Chinese Jungar breeding site on 27 May 1998, within the laying period observed for this population in 1998 (Combreau et al. 2002). After the reproductive season, which lasted about 4-5 months, houbara completed their outward migration following the same flyway pattern to the Cholistan-Thar Desert in 20-93 days, which is in the range of outward migration duration values observed by Combreau et al. (1999) in the case of Kazakh houbara. Like many other bird species wintering in the Indian subcontinent (Dolnik 1990), houbara from the Thar Desert crossed the deserts of Kazakhstan, Uzbekistan and Turkmenistan, avoiding the mountain massifs of Hindu Kush, Pamir, Tien Shan and Himalaya.

During their migration, houbara travelled at an average speed of up to $220 \mathrm{~km} \mathrm{day}^{-1}$ and covered a total distance up to $4,400 \mathrm{~km}$ between their departure and destination points; they can thus be considered as long-distance migrants (Berthold 1993). The number of long stopovers by our four houbara during their outward migration was similar to that observed for Kazakh houbara (1-2 stopovers; Combreau et al. 1999), even if the distances from breeding grounds and wintering grounds were greater (996 km versus $317 \mathrm{~km}$ and 2,100$4,400 \mathrm{~km}$ versus $1,600-2,320 \mathrm{~km}$, respectively). Excluding one long stopover of 79 days made by female $B$, the total duration of long stopovers was lower (9 days versus 35 days) than the houbara monitored by Combreau et al. (1999), of which several stopovers lasted more than 50 days. The distance between short stopovers was similar to Kazakh birds (95-1,337 km versus $111-1,375 \mathrm{~km}$ ).

The duration of houbara outward migration was generally shorter than that of homeward migration. Mean daily travel distances during homeward migration were half those during outward migration. This was reflected in the frequency of both long and short stopovers, which was higher during homeward migration than outward migration. During homeward migration, the first long stopovers were also located closer to the departure point than during outward migration. Therefore, the houbara monitored in this study contrasted with other longdistance flying species, for which the number of stopovers (the function of which is mainly to refuel the fat reserves to continue the journey; Alerstam and Hedenström 1998), the distance and the duration of homeward migration are generally lower than for the outward migration (Berthold 1996).

Differences between homeward and outward migration observed in our study may have been due to physiological constraints (i.e. the necessity of refuelling 
because of bad condition of birds on their departure to breeding grounds). In the Cholistan Desert, most rainfall occurs through the short July-September monsoon period and the rest of the year, especially winter, is dry (Rahmani and Soni 1997, Rawat and Wikramanayake 2001). Local food may then be insufficient in March for houbara to undertake a long migratory journey to their breeding grounds without stopping on the way. Moreover, houbara lay eggs soon after their arrival on the breeding grounds (3-5 days; Combreau et al. 2002). According to their mean clutch size $(4 \pm 0.8 \mathrm{SD})$ and the weight of egg in relation to female body weight ( $5 \%$; NARC unpublished data), houbara may be qualified as "capital breeders" (sensu Meijer and Drent 1999), i.e. with a total reliance upon stored reserves for egg-formation. Stopovers would then facilitate the acquisition of such reserves before their arrival on breeding grounds.

Differences between outward and homeward migration may also be explained by changes in weather conditions, with winds more favourable in autumn than in spring. A rough examination of extratropical storm tracks during 1998 showed strong winds between March and May in the region from the Aral Sea, south Lake Balkash to Mongolia (NASA-Godard Institute for Space Studies, New York, USA; http:/ / www.giss.nasa.gov/data/stormtracks).

Although our study is based on a small sample size of just four birds, and needs further investigation, this work and Combreau et al. (1999) reveal the importance of south Kazakhstan (Taukum, Muyunkum, Kyzylkum) and Afghanistan (Registan) deserts as stopovers for migrating eastern houbara populations. For a long-distance migrant species such as Asian Houbara, conservation issues should be addressed at the local scale through the prevention of poaching and over-hunting activities in Pakistan, but also at a broader scale by preventing hunting at stopover sites in Kazakhstan, some of which are also breeding grounds for the Asian Houbara population (Osborne et al. 1997, Combreau et al. 1999, Combreau et al. 2001). This can only be achieved through international collaboration between Central Asian countries, from the breeding grounds of China to the wintering grounds of the Indian subcontinent. In this context, the agreement currently under discussion between Saudi Arabia and the Bonn Convention on Migratory Species (CMS) must be urgently ratified by all parties to set the legal framework for implementing a specific conservation action plan for this migratory species.

\section{Acknowledgements}

The authors are grateful to HH Sheikh Khalifa bin Zayed Al Nahyan, Crown Prince of Abu Dhabi and chairman of the board of the Environmental Research and Wildlife Development Agency, and $\mathrm{HH}$ Sheikh Hamdan bin Zayed Al Nahyan, deputy chairman. Special thanks to HE Mr Mohammed Al Bowardi, Managing Director, Mr Majid Al Mansouri, Secretary General, for their support, and Mr Mohammed Saleh for his constant help.

\section{References}

Alerstam, T. and Hedenström, A. (1998) The development of bird migration theory. J. Avian Biol. 29: 343-369. 
Bailey, T. A., Silvamose, C. D., Naldo, J., Combreau, O., Launay, F., Wernery, U., Kinne, J., Gough, R. and Manwell, R. (1999) Health considerations of the rehabilitation of illegally traded houbara bustards Chlamydotis undulata macqueenii in the Middle East. Oryx 34: 325-334.

Berthold, P. (1993) Bird migration: a general survey. Oxford: Oxford University Press.

Berthold, P. (1996) Control of bird migration. London: Chapman \& Hall.

Collar, N. J. (1979) The world status of the houbara: a preliminary review. Symposium papers on the Houbara Bustard Chlamydotis undulata. C. L. Coles \& N. J. Collar, eds. FISG/CIC/Game Conservancy, Athens, Greece. (no pagination).

Combreau, O., Launay, F., Al Bowardi, M. and Gubin, B. (1999) Outward migration of Houbara bustard from two breeding areas in Kazakhstan. Condor 101: 159-164.

Combreau, O., Launay, F. and Lawrence, M. (2001) An assessment of annual mortality rates in adult sized migrant houbara bustards (Chlamydotis [undulata] macqueenii). Anim. Conserv. 4: 133-141.

Combreau O., Qiao J., Lawrence, M., Gao, X., Yao, J., Yang, W. and Launay, F. (2002) Breeding success in a Houbara Bustard, Chlamydotis [undulata] macqueenii, population in the eastern fringe of the Jungar basin, People's Republic of China. Ibis 144: E45-E56.

Del Hoyo, J., Elliot, A. and Sargatal, J. (1996) Handbook of the birds of the world, 3. Barcelona: Lynx Edicions.

Dolnik, V. R. (1990) Bird migration across arid and mountainous regions of Middle Asia and Kazakhstan. Pp. 368-386 in E. Gwinner, ed. Bird migration, physiology and ecophysiology. Berlin, New York: Springer-Verlag.

Goriup, P. D. (1997) The world status of the houbara bustard Chlamydotis undulata. Bird Conserv. Internat. 7: 373-397.

Knox, A. G., Collinson, M., Helbig, A. J., Parkin, D. T. and Sangster, G. (2002) Taxonomic recommendations for British birds. Ibis 144: 707-710.

Meijer, T. and Drent, R. (1999) Re-examination of the capital and income dichotomy in breeding birds. Ibis 141: 399-414.

Osborne, P. E., Al Bowardi, M. and Bailey, T.A. (1997) Migration of the Houbara Bustard Chlamydotis undulata from Abu Dhabi to Turkmenistan; the first results from satellite tracking studies. Ibis 139: 191-196.

Rahmani, A. R. and Soni, R. G. (1997) Avifaunal changes in the Indian Thar Desert. J. Arid Environ. 36: 687-703.

Rawat, G. S. and Wikramanayake, E. D. (2001) The Thar desert (IM1304). In E. D. Wikramanayake, et al., eds. Terrestrial ecoregions of the Indo-Pacific: a conservation assessment. WWF. Washington, D.C.: Island Press.

Seddon, P., Launay, F., van Heezik, Y. and Bowardi, M. (1999) Methods for live trapping houbara bustards. J. Field Orni. 70: 169-118.

Taillade, M. (1992) Animal tracking by satellite. Pp. 149-160 in I. G. Priede and S. M. Swift eds. Wildlife telemetry. Remote monitoring and tracking of animals. Chichester, U.K.: Ellis Horwood.

Webster, M. S., Marra, P. P., Haig, S. M., Bensch, S. and Holmes, R. T. (2002) Links between worlds: unravelling migratory connectivity. Trends Ecol. Evol. 17: 76-83.

\section{CHRISTOPHE TOURENQ, OLIVIER COMBREAU, MARK LAWRENCE and FREDERIC LAUNAY}

National Avian Research Center, Environmental Research and Wildlife Development Agency, PO Box 45553, Abu Dhabi, United Arab Emirates. E-mail: ctourenq@erwda.gov.ae

Received 2 January 2003; revision accepted 26 September 2003 